\title{
Do Students Turn Over Their Rights When They Turn in Their Papers? A Case Study of Turnitin.com
}

\author{
Stephen Sharon \\ Touro Law Center
}

Follow this and additional works at: https://digitalcommons.tourolaw.edu/lawreview

Part of the Contracts Commons, Intellectual Property Law Commons, Internet Law Commons, and the Legal Ethics and Professional Responsibility Commons

\section{Recommended Citation}

Sharon, Stephen (2012) "Do Students Turn Over Their Rights When They Turn in Their Papers? A Case Study of Turnitin.com," Touro Law Review. Vol. 26: No. 1, Article 7.

Available at: https://digitalcommons.tourolaw.edu/lawreview/vol26/iss1/7

This Intellectual Property Comments is brought to you for free and open access by Digital Commons @ Touro Law Center. It has been accepted for inclusion in Touro Law Review by an authorized editor of Digital Commons @ Touro Law Center. For more information, please contact Iross@tourolaw.edu. 
Do Students Turn Over Their Rights When They Turn in Their Papers? A Case Study of Turnitin.com

\section{Cover Page Footnote}

26-1 


\title{
Do Students Turn OVer Their Rights When TheY TURn in Their Papers? A Case Study OF TURNITIN.COM
}

\author{
Stephen Sharon
}

Turnitin is a rapidly growing online anti-plagiarism service subscribed to by thousands of schools in the United States. Though the pursuit of honesty and integrity are at the heart of our academic institutions and the Turnitin anti-plagiarism service, there is a fatal flaw in its execution. This Comment examines the copyright and fair use arguments presented by four Virginia students asserting that Turnitin violated their intellectual property rights. This Comment goes beyond the facts of the four Virginia students to explore the root issues of a service that collects and distributes the copyrighted works submitted to it by hundreds of thousands of students.

Despite the unsuccessful attempts to convince the District Court and Circuit Court of Appeals that their rights were violated it is patently clear that the rights of the students were infringed. This Comment delves deep into not only the copyright and fair use arguments, but also scrutinizes the contract issues and privacy implications of a service like Turnitin's.

Unfortunately, students will always find ways to cheat, but it is unacceptable to cheat them out of their legal rights. Educators should lead by example and respect the privacy and intellectual property rights of all students, even if the consequences are difficult to accept.

\footnotetext{
* B.A., University of Maryland, 2005; J.D., Touro College, Jacob D. Fuchsberg Law Center 2009. Special thanks to Professor Rena Seplowitz for her guidance, patience, and impeccable attention to detail. Thanks also to my wife, a teacher, and family for their valuable input. and support.
} 


\section{INTRODUCTION}

Students across the country already dread their next writing assignments, which often mean hours of research, thinking, and creative expression. Should students also fear that their legal rights are being infringed the day they turn in their papers? Thousands of public and private schools have mandated that students submit their papers to an anti-plagiarism service known as Turnitin. ${ }^{1}$ On the surface this seems reasonable, given the ease with which less scrupulous students copy and paste portions of papers they did not write or even outsource their assignments entirely. Just beneath the surface, however, is the paranoia that every student is a plagiarist and must be investigated. Rather than investigate suspicious papers, all students submit their work to Turnitin for analysis. ${ }^{2}$ Before delving into the many legal issues that surround this situation, it is prudent to first examine plagiarism in the United States and the Turnitin process. ${ }^{3}$ This Comment will first examine the background of plagiarism as it applies to Turnitin, followed by a discussion of issues pertaining to contract, misappropriation, copyright, fair use, privacy, and alternatives to Turnitin.

\section{A. Plagiarism}

Sadly, plagiarism is not a new phenomenon in this country. Everything, except personal ethics, encourages plagiarism by rewarding the finished product and ignoring the work that went into it. Both in the educational arena and in professional life, people care about results and measure other individuals accordingly. Therefore, little in-

\footnotetext{
1 Turnitin Home Page, http://www.turnitin.com (last visited Sept. 16, 2009).

2 See Turnitin, How Turnitin Plagiarism Prevention Works, http://turnitin.net/ static/pdf/datasheet_cycle.pdf (last visited Sept. 16, 2009) (stating that Turnitin has archived over ten million student papers and adds 10,000 more papers to the archive daily); Douglas MacMillan, Looking Over Turnitin's Shoulder, Bus. WK. ONLINE, Mar. 13, 2007, available at 2007 WLNR 4713614 (indicating that over 120,000 papers are added daily); Turnitin, Products, http://tumitin.com/static/products.html (last visited Sept. 16, 2009) [hereinafter Products] (indicating that over ninety million student papers are part of the database).

3 Plagiarism occurs worldwide, but the scope of this Comment only encompasses the United States. A significant portion of plagiarized material originates from the Internet and the majority of the Internet is in English. See MacMillan, supra note 2 (reporting that Internet plagiarism is prevalent and increasing); Internet World Stats, Internet World Users by Language, http://www.internetworldstats.com/ stats7.htm (last visited Sept. 16, 2009) (reporting that English is by far the most prominent language on the Internet).
} 
centive exists to behave ethically in achieving the desired result. Compounding this are the lazy and overworked students who do not want to, or cannot, devote more time to each paper. Plagiarism is the easy way out and every student knows of its potential. Plagiarism does not discriminate and is practiced both by the students who "want to get by" and the ones who want to excel. ${ }^{4}$

Understanding the potential benefit of plagiarism, it is no surprise that students yield to its temptation. ${ }^{5}$ The current concern is twofold in that it is now both easier to plagiarize, given the Internet, and harder for teachers to detect. Only ethics and higher personal standards can reduce the temptation to plagiarize. Turnitin is aiming to swiftly take care of the second concern, but even the former issue can be the subject of debate given the modern trend of outsourcing work. Students observe companies outsourcing and have recently followed their initiative and have begun outsourcing their own schoolwork. The New York Times took it for granted that students outsource essay writing to India when it published an article reviewing the quality of three different paper mills. ${ }^{6}$ Lest one think that only American students succumb to the pressure to plagiarize essays, there is evidence that the trend is global. ${ }^{7}$

Essay outsourcing has not reached epidemic levels yet, but now that students as young as ten years old are being exposed to outsourced education, the future is uncertain. Outsourcing English tu-

4 See, e.g., David Zhou, Student's Novel Faces Plagiarism Controversy, THE HARVARD CRIMSON, Apr. 23, 2006, http://www.thecrimson.com/article.aspx? ref $=512948$ (detailing how a Harvard student named Kaavya Viswanathan allegedly plagiarized several passages in her novel "How Opal Mehta Got Kissed, Got Wild, and Got a Life"); see also CNN, Harvard Author Faces Further Allegations of Borrowing, May 5, 2006, http:/www.cnn.com/2006/SHOWBIZ/books/05/02/youngauthor.ap/index.html (stating that Viswanathan's novel was pulled from store shelves, her second book deal canceled, and a former employer hired a service to investigate whether work for them was plagiarized); Davit Zhou \& Paras D. Bhayani, 'Opal' Similar to More Books, ThE HaRvard Crimson, May 2, 2006, http://www.thecrimson.com/ article.aspx?ref=513213 (noting that development of the movie based on Viswanathan's work was also subsequently terminated).

5 See Samuel J. Horovitz, Two Wrongs Don't Negate a Copyright: Don't Make Students Turnitin if You Won't Give it Back, 60 FLA. L. REV. 229, 233-34 (2008) (indicating that forty percent of students admit to "cut-and-paste plagiarism").

6 Charles McGrath, Outsourcing Homework; At \$9.95 a Page, You Were Expecting Poetry?, N.Y. TIMES, Sept. 10, 2006, at 1.

7 See BBC News, Online Essays 'Sold Many Times,' Apr. 8, 2005, http://news.bbc.co.uk/ 1/hi/wales/4421667.stm (reporting that a computer expert in England tracked essays being sold on eBay, uncovered that the same essay was being passed off multiple times, and reported that the sellers provided advice on how to trick anti-plagiarism software). 
toring might be more cost effective in the short term, ${ }^{8}$ but will the students be able to draw the line between acceptable and unethical outsourcing? Acceptable outsourcing such as remote tutoring and document review is acceptable, but young adults may not realize the fine line between having someone help them brainstorm or edit their papers and actually writing portions of it on their behalf. The answer only becomes more elusive as schools now outsource grading essays ${ }^{9}$ in the same way the students assigned to write them might have outsourced their writing. This cycle does not begin and end with high school and college students, but rather, it extends to legal writing as well. Companies such as Pangea $3^{10}$ are available to draft patent applications, contracts, and briefs for a fraction of the cost of United States based firms, ${ }^{11}$ proving that even the legal profession is not immune.

It is evident that Turnitin and similar services face a technical and sociological battle in combating plagiarism. Spotting a plagiarized paper is not trivial and places an unnecessary burden on the world's teachers. ${ }^{12}$ Turnitin's algorithm mimics what a human might look at to detect plagiarized work, such as blocks of identical text and patterns of similar sentences, ${ }^{13}$ but it cannot be trusted to follow the law without significant human intervention.

8 Saritha Rai, Latest in Outsourcing: Homework; Tutoring Cheaper via India Hookup, INT'L HERALD TRIB., Sept. 8, 2005, at 14 (detailing how two California parents chose to switch from conventional in-person tutoring to a service in India which tutors English, math, and science for twenty dollars per hour. The parents cited the cost savings, twenty dollars versus fifty dollars per hour, as the primary reason for switching; however, they noted that the quality of the service was comparable).

9 Brahm Resnik, School Outsourced Essays to India, NAT'L BROADCASTING CORP. KPNX 12 NEws, Aug. 16, 2008, http://www.azcentral.com/12news/news/ articles/2008/08/16/200 80816schooloutsource08162008-CR.html (reporting that an online charter school in Arizona, owned by the largest charter company in the country, outsourced portions of essay grading to India but plans to channel some of the work to graduate students in Arizona).

${ }_{10}$ Pangea3 Home Page, http://www.pangea3.com/index.html (last visited Aug. 18, 2009).

1 See Arin Greenwood, Manhattan Work at Mumbai Prices, 93 A.B.A. J. 36 (2007) (discussing the expanding market for "legal process outsourcing").

12 BBC News, Teachers Voice Plagiarism Fears, Jan. 18, 2008, http://news.bbc.co .uk/1/hi/education/7194772.stm (quoting Mark Jones of Wirral Metropolitan College as saying, "you haven't got enough hours in the day to search out where information was plagiarised [sic] from to prove it," in response to a poll which revealed that over half of the professors believed that a quarter of their students had submitted plagiarized work).

13 See MacMillan, supra note 2. 
B. Turnitin

\section{Turnitin's Business Model}

Turnitin does not spend its time and money fighting plagiarism because it is a corporate "good samaritan," a nonprofit organization, or funded by the government. Turnitin is a for profit company, which has doubled its membership every year for the last seven consecutive years. ${ }^{14}$ Its business plan revolves around charging schools an average of eighty cents per student per year. ${ }^{15}$ There is nothing wrong with making money by fighting plagiarism, but at least four high school students in Virginia think that at least some of those profits are ill gained. ${ }^{16}$

Turnitin is able to sell its service at a premium because of two factors: first, Turnitin has an effective algorithm ${ }^{17}$ that no one else

14 Randy Dotinga, Electronic Snoops Tackle Copiers, WIRED, Apr. 2, 2004, http://www.wired.com/techbiz/media/news/2004/04/62906 (quoting Turnitin's parent company as having ten million dollars in revenue in 2003).

15 Maria Glod, Students Rebel Against Database Designed to Thwart Plagiarists, Charleston GazetTe \& Daily Mall, Sept. 25, 2006, at 6D.

16 A.V. v. iParadigms, L.L.C., 544 F. Supp. 2d 473, 478, 484-85, 486-87 (E.D. Va. 2008) (rendering a decision that is the inspiration for this Comment; however, in many examples I diverge from the local laws in an effort to make the Comment more relevant to readers in other states. For this same reason, and for the sake of clarity, this Comment also ignores the four counterclaims brought by iParadigms: (1) indemnification based on the Usage Policy; (2) trespass to chattels; (3) violation of the Computer Fraud and Abuse Act; and (4) violation of the Virginia Computer Crimes Act, because iParadigms initially failed on each claim); A.V. ex rel. Vanderhye v. iParadigms, L.L.C., 562 F.3d 630, 647 (4th Cir. 2009) (illustrating that since this initial decision, the Fourth Circuit Court of Appeals has reversed the decision with respect to the counterclaims and affirmed the fair use finding); Anon-ablogger, Students Settle with TurnItIn, Aug. 2, 2009, http://a-non-a.blogspot .com/2009/08/students-settle-with-turnitin.html (reporting that an additional appeal to the United States Supreme Court was underway before a settlement was reached).

17 See Turnitin, New Features, http://turnitin.com/static/new tii_features_090630.html (last visited Aug. 18, 2009) (illustrating that the Turnitin system has seen improvements over the years); but see John Royce, Trust or Trussed? Has Turnitin.com Got It All Wrapped Up?, TEACHER LIBR., Apr. 1, 2003, at 26, http://www.teacherlibrarian.com/tlmag/v_30/v_ 30_4_feature.html.

I found that Turnitin found no matches for material lifted from usenet discussion groups and discussion lists; found no matches for material lifted from online encyclopedias; and did not track down material lifted from journals located in subscription databases ....

.... It several times made false accusations of plagiarism, but missed by far the greater part of the material I really had plagiarized, missing 15 
has, giving its system the effectiveness it needs to convince large school districts to sign up; ${ }^{18}$ and second, the database of documents against which Turnitin unleashes its algorithm is massive and growing daily. ${ }^{19}$ Understanding the entire process of how the service works will assist in Section IV, which analyzes the copyright issues. ${ }^{20}$

\section{The Turnitin Submission Process}

Once a school-or, in some instances, an individual instructor-subscribes to the Turnitin service, the next step is for students to submit their work for grading. Rather than bringing their printed essays to class, students submit the essays to Turnitin, which analyzes them before making them available to the teacher. ${ }^{21}$ The preferred method for students to submit papers is to create Turnitin user accounts and submit the papers online. However, it should be noted that instructors can also submit student papers, thereby bypassing the Turnitin student user agreement. ${ }^{22}$ Once a paper has been submitted, Turnitin analyzes the paper and produces an "Originality Report"23 for the instructor. ${ }^{24}$ The report aims to graphically show the instructor which portions of a paper are similar to content in the Turnitin database. $^{25}$ For the purposes of this Comment, the focus will be on the

of 18 plagiarized passages in one of the essays.

Id. Ordinarily, one example of a false positive amongst thousands of positive reviews might be acceptable, but in a student's educational career a single failure because of academic dishonesty can destroy their reputation and even future employment opportunities.

18 See Greg Reihman, On the Effective and Appropriate Uses of Turnitin, LEHIGH U. FACULTY DEVELOPMENT, http://www.lehigh.edu/ infdli/UsingTurnitin.htm (last visited Sept. 23,2009 ) (outlining many of the limitations of Turnitin and cautioning professors not to rely on it exclusively).

19 Products, supra note 2.

20 See infra Section IV(A).

21 MacMillan, supra note 2.

22 Reihman, supra note 18 (cautioning, "If you submit a student's work without his or her knowledge, you may be in violation of FERPA regulations if the work contains the student's [sic] name, student id number, or other personally identifiable information." And conclusively proving that a student's paper can be added to the database without ever agreeing to any usage terms with Turnitin, aside from the potential FERPA violations that the instructor might be subject to); see also infra Section V.B.

${ }^{23}$ Turnitin, Q\&A, https://www.turnitin.com/resources/documentation/tumitin/sales/Turn itin_Q and_A.pdf (last visited Aug. 18, 2009).

${ }^{24}$ Turnitin, Viewing Originality Reports, http://turnitin.com/static/Knowledge_center/ Viewing_Originality_Reports.asp (last visited Aug. 18, 2009).

${ }^{25} \mathrm{See}$ Turnitin, Training Center, http://turnitin.com/static/training.html (last visited Aug. 
comparisons with other student works.

In the event instructors wish to see the original content that they believe their students may have plagiarized, they can request copies of the papers from the original students' instructors. ${ }^{26}$ Significantly, the original student has no notice that his or her work matches another student's work and may be emailed without his or her knowledge. Then, the current instructor has a chance to compare the two papers to independently determine whether any plagiarism took place. Turnitin emphasizes that instructors, and not computers, make the final determination ${ }^{27}$ as to whether a paper was plagiarized.

At this stage the student's paper has already been added to the Turnitin database. There is some dispute as to whether the papers are stored in their entirety, or just as digital fingerprints, but this debate can be safely disregarded because digital fingerprints are useless ${ }^{28}$ in

18,2009 ) (containing training videos that demonstrate the different ways the system can display a student's work with the corresponding matched text online).

${ }^{26}$ See TURNITIN, TURNITIN INSTRUCTOR USER MANUAL 46 (2009), available at http://turnitin.com/resources/documentation/turnitin/training/en_us/Instructor_Manual_en_u s.pdf.

If the paper is from a class controlled by another instructor, no direct access to this paper can be provided. To view the paper, the instructor must request permission from the instructor in possession of the paper by clicking on the link to the source and then using the permission request button. Turnitin will auto-generate an e-mail request to the instructor who controls the paper. The instructor can reply via e-mail to the user if the request is granted.

Id.

27 Turnitin, Usage Policy, http://www.turnitin.com/static/usage_policy.html (last visited Sept. 23, 2009) [hereinafter User Agreement].

You further agree to exercise $[y]$ our independent professional judgment in, and to assume sole and exclusive responsibility for, determining the actual existence of plagiarism in a submitted paper with the acknowledgement and understanding that the Originality Reports are only tools for detecting textual similarities between compared works and do not determine conclusively the existence of plagiarism....

Id.

28 See Mike Smit, TurnItIn.com-Copyright and "Fingerprints", http://mikes mit.com/ page.php?id=23 (last visited Sept. 4, 2009) (discussing why fingerprints would not be effective). This Author's own explanation is as follows: Turnitin claims to only keep a digital fingerprint and not an entire plain text copy of the work, but this is difficult to believe. A brief explanation of cryptographic hashes will put this in context. Digital fingerprints, or hash functions as they are more often referred to, are useful because they are (1) easy to compute, (2) cannot be reversed, and (3) even similar inputs will produce different hashes. The second point is, arguably, the most important and is the reason why computers often store hashes of passwords rather than the plain text (in case a password list is stolen it will be 
this type of situation because full text copies are the only plausible solution. In theory, professors and schools have the option of telling Turnitin not to add their students' works to the database, but this option is rarely exercised by schools ${ }^{29}$ or complied with by Turnitin. ${ }^{30}$

\section{CONTRACT}

When students first create their user accounts, they are presented with a "User Agreement" that they must accept before they can proceed. ${ }^{31}$ Online contracts are a relatively recent addition to contract law, but it is already well established that a contract can be validly entered into online by clicking "Accept," with the same force and effect as a written contract. ${ }^{32}$ The following contract covers nearly every student paper that ends up in Turnitin's database: ${ }^{33}$

With regard to papers submitted to the Site, You hereby grant iParadigms a non-exclusive, royalty-free, perpetual, world-wide, irrevocable license to reproduce, transmit, display, disclose, archive and otherwise use in connection with its Services any paper You submit to the Site whether or not originally sub-

useless because the password text cannot be reversed out of the hash). A hash is a one-way function used to compare two inputs to see if they are identical; if the hashes match, they are. If a student paper was hashed, its only value would be if the identical paper was later submitted. In that case, the hashes of the papers would match and it would be an obvious red flag. However, this would defeat the value of the Turnitin system, which searches for even short strings of matching words. Changing even one letter of an essay would produce a radically different hash and no match would be detected. Even if some form of hash were produced and used in the analysis, the hash would be a derivative work of the submitted paper and Turnitin would have to contend with the author's exclusive right of creating derivative works.

29 Not surprisingly, most plagiarized papers originate from friends in the same school or from students of previous years. If a school chooses not to add its students' works to the Turnitin database, it essentially locks out one of its best chances at detecting plagiarism.

${ }^{30}$ See Mike Smit, TurnItIn.com: Removing Information From Their Database, http://www.mikesmit.com/page.php?id=24 (last visited Sept. 4, 2009), in which Smit asked Turnitin to stop crawling his web site. Only after multiple email exchanges and over three months passing did Turnitin finally agree to comply with the request. As a point of reference, Smit notes that to accomplish the same task with the popular search engine Google, it only took the click of a button.

31 See User Agreement, supra note 27, at 1.

32 See Forrest v. Verizon Commc'ns, Inc., 805 A.2d 1007, 1011 (D.C. 2002).

33 iParadigms, 544 F. Supp. 2d at 478; see also Reihman, supra note 18, at 2 (indicating that a professor can submit a student work without the student's knowledge or consent). 
mitted in connection with a specific class. ${ }^{34}$

If this contract is enforceable, there is no need to discuss the copyright issues because the students will have already licensed their works to Turnitin. To continue with the copyright analysis it is imperative to invalidate this contract.

\section{A. Contract with a Minor}

In the majority of jurisdictions, a contract entered into by a minor is voidable upon the minor reaching the age of majority. ${ }^{35} \mathrm{~A}$ significant percentage of Turnitin users are high school students, almost all of whom are probably minors. One caveat to the general rule stated above is pointed out in iParadigms, wherein the United States District Court explained that once a minor accepts the benefit of a contract, they no longer have the ability to revoke it. ${ }^{36}$ On a semantic level this might be true, however, an in depth analysis of the contract may favor the students.

For the students to revoke the contract they need to show that they received no benefit or alternatively that they can return the benefit conferred on them. The court claims that the students were the recipients of not one but two distinct benefits: first, the students gained standing to sue; and second, they gained the ability to submit their papers for a grade. ${ }^{37}$ Because neither of these benefits can be returned in a realistic manner, the only remaining option is to prove that these are not, in fact, benefits.

The first benefit - standing - can hardly be considered a benefit given that the students could have sued Turnitin even without a contract. If the students had the ability to sue Turnitin before the contract, it is difficult to accept that regaining this ability is a truly conferred benefit of the contract. Consider that if there was no user agreement, students would still have standing to sue for copyright in-

\footnotetext{
${ }^{34}$ User Agreement, supra note 27, at 4. Also, note that "otherwise use" ostensibly includes distribution.

355 WiLliston ON CONTRACTS $\$$ 9:9 (4th ed. 2007).

36 iParadigms, $544 \mathrm{~F}$. Supp. 2d at 481 (explaining that in Virginia the infancy defense cannot function as a sword, because it was intended only to protect infants). See also 5 WILLISTON ON CONTRACTS $§ 9: 14$ (4th ed. 2007) ("If an infant enters into any contract subject to conditions or stipulations, the minor cannot take the benefit of the contract without the burden of the conditions or stipulations.").

${ }^{37}$ Id.
} 
fringement. Furthermore, if entering into a contract is itself a benefit, then no minor would ever be able to successfully rescind it because they would have already accepted a benefit merely by entering the contract. This runs directly counter to widely accepted case law that provides for the infancy defense. ${ }^{38}$

The second benefit the students allegedly received-the ability to turn in their papers-is as valuable as the first benefit. Once again, the students had the ability to submit their work before Turnitin ever existed. It is a shock to notions of fair play that the only alternative to submitting papers through Turnitin is a failing grade in many schools. ${ }^{39}$ This argument is further weakened when one considers that Turnitin does not even confer the benefit, but rather the schools do. ${ }^{40}$

With no benefit received, students can exercise their power and rescind the contract they entered into with Turnitin, granting them royalty-free, perpetual, irrevocable licenses to their work. Accepting this in the context of iParadigms is particularly damaging, as the students included disclaimers at the top of the papers they submitted. ${ }^{41}$ The entire discussion of copyright law and fair use hinges on accepting that there is no contract between the students and Turnitin. $^{42}$

38 See, e.g., Pieri v. Nebbia, 34 N.Y.S.2d 317, 318 (Monroe County Ct. 1942) ("[A]ll unexecuted contracts made by a minor except for necessaries, while not absolutely void, are voidable at his election.").

39 See iParadigms, 544 F. Supp. $2 d$ at 478.

40 In iParadigms, the students attempted to assert a duress claim, which was rejected by the Court because it should have been asserted against their school and not against Turnitin. In other words, schools compel their students to submit their papers to Turnitin, therefore Turnitin holds no liability (for the duress of another) on this claim. It follows logically that Turnitin should not be able to claim that it conferred a benefit on the students, letting them submit papers, which is an essential function of the school. If a third party is not liable (for duress) it cannot take claim to a benefit it did not directly confer. Similarly, Turnitin cannot claim that it benefits the students by preventing them from getting lower grades than peers who submitted superior, yet plagiarized work. iParadigms, 544 F. Supp. $2 \mathrm{~d}$ at 481.

${ }^{41}$ Id. at 478 . The disclaimer mentioned that the students did not consent to having their works archived by Tumitin. Accepting that the User Agreement is voidable, this disclaimer might be viewed as a new offer that Turnitin then ratified by accepting the paper. In this case, Turnitin would be liable for breach of contract and potentially for copyright infringement as well.

42 Technically, even if there is a contract with some of the students, there are still others whose works are submitted without their knowledge or consent. Turnitin may attempt to shift the blame to these instructors, but its system not only makes it simple to submit works without student knowledge, it invites the practice as well. 


\section{B. Contract of Adhesion}

Turnitin faces an equal number of contractual challenges with respect to adult users. McKee v. $A T \& T$ Corp. ${ }^{43}$ presents a useful example with which to compare the present facts. In $M c K e e$, an AT\&T phone service subscriber brought a class action suit alleging that AT\&T wrongly charged the class a surcharge. ${ }^{44}$ AT\&T fought for arbitration as per the signed contract with the customers, but the Supreme Court of Washington found the contract to be unconscionable ${ }^{45}$ because it was one-sided and overly harsh. ${ }^{46}$ The students opposing Turnitin are in a similar situation. The Turnitin user agreement is even more one-sided than the consumer agreement with AT\&T because it is often entered into by minors with not only less bargaining power than adults, but without even the basic legal knowledge that they have a chance to bargain in the first place. ${ }^{47}$ The end result, though, is the same: whether infant or adult, the contract is void. The contract is also overly harsh in that it requires students to, "grant iParadigms a non-exclusive, royalty-free, perpetual, worldwide, irrevocable license to reproduce, transmit, display, disclose, archive and otherwise use [their] Communications [and any paper they submit] on the Site or elsewhere for [its] business purposes."48 In addition to being forced into signing over a royalty-free, worldwide license, the license survives the termination of the user agreement. ${ }^{49}$ Other provisions are equally harsh in that they prevent students from submitting Digital Millennium Copyright Act ("DMCA")

$43 \quad 191$ P.3d 845 (Wash. 2008).

44 Id. at 848 .

$45 \mathrm{Id}$. at 857,858 (listing the following as offensive: prohibition of class actions, mandatory arbitration, forced secrecy of arbitration results, no punitive damages, no attorneys fees, shortened statute of limitations, and acceptance of New York law). The Court also noted that the plaintiff had no meaningful choice because everyone should have access to phone service and there is rarely meaningful competition. Id.

46 Id. at 857.

47 User Agreement, supra note 27, at 1 (prohibiting children ages fourteen to seventeen to access the site without a parent or guardian present). Of course, the minor that navigates to the site without knowing of the provision in advance automatically violates it. The Agreement goes on to say that the parent or guardian must then be the one to click "Accept" and not the student. Id. How this may impact on the enforceability of the contract will not be addressed in this Comment.

48 Id. at 4 . A nearly identical provision expands this to cover papers submitted and not just communications made on the site.

49 Id. ("This license shall survive the termination of the User Agreement."). 
notices ${ }^{50}$ and disclaim any warranty that the Turnitin site is safe or secure. $^{51}$ Arguably, the harshest provision regards the archiving of papers. Students are never entitled to injunctive relief, ${ }^{52}$ and submit that their sole remedy for dissatisfaction with the site is to stop using it. $^{53}$

Likewise, in McKee, the contract was found to be overly harsh because AT\&T had no competition and used its control of the market to force unconscionable terms on its customers. ${ }^{54}$ Taking these factors into consideration, and the fact that the students have no meaningful choice but to agree to the contract, or face failing their classes, it is plausible that a court might find the contract to be unconscionable. ${ }^{55}$

\section{MISAPPROPRIATION}

The common law cause of action of misappropriation applies when one party procures the property of another for their own benefit. ${ }^{56}$ At first glance, this seems to apply to Turnitin because Turnitin

${ }^{50}$ Id. at 5. ("You hereby acknowledge that the DMCA notice does not cover a circumstance in which a paper or other Communication You submitted has been archived on the Site. You agree not to submit a DMCA notice claiming direct infringement by iParadigms.").

51 User Agreement, supra note 27, at 5.

You acknowledge and agree that iParadigms does not operate or control the internet and that: (i) viruses, worms, trojan horses, or other undesirable data or software; or (ii) unauthorized users (e.g., hackers) may attempt to obtain access to and damage user's data, computers, or networks. iParadigms shall not be responsible for such activities.

Id. (emphasis omitted).

${ }^{52}$ Id. at 6 ("You agree that under no circumstances shall you be entitled to injunctive relief with regard to the use or archiving of any paper submitted to the site.") (emphasis omitted).

${ }^{53}$ Id. ("If you are a student or instructor, your sole remedy for dissatisfaction with the site, the services, and/or hyperlinked web sites is to stop using the site and/or those services.") (emphasis omitted).

${ }^{54}$ McKee, 191 P.3d at 858.

55 The court in McKee also took note of the fact that each individual claim was worth very little, only twenty dollars per year, but over time, and taking into account many people in a similar position, AT\&T was benefiting immensely from its wrongdoing. Id. at 848 . Similarly, students across the country taking issue with Tumitin each have claims that seem insignificant on their own, but in aggregate are substantial.

${ }^{56}$ See, e.g., Hauck Mfg. Co. v. Astec Indus. Inc., 375 F. Supp. 2d 649, 661 (E.D. Tenn. 2004) ("Under Tennessee common law, a cause of action for conversion requires a plaintiff to prove (1) the appropriation of another's property to one's own use and benefit, (2) by the 
acquires the papers of students and then uses them to market a service. However, misappropriation, and other common law causes of action, are preempted by the federal copyright law. ${ }^{57}$ On the other hand, when analyzing works that cannot be copyrighted, the misappropriation claim will not be preempted. ${ }^{58}$

\section{COPYRIGHT}

\section{A. Fundamentals}

The fundamentals of copyright law are based heavily on both statutes and often conflicting case interpretations, and are, therefore, the most applicable in this Comment. The issues concerning copyright are at the heart of the dispute between the students and Turnitin. Copyright protection was authorized by the U.S. Constitution for the purpose of promoting "Science and useful Arts." 59 To implement this lofty goal, Congress enacted the first Copyright Act in $1790 .{ }^{60}$ The current Copyright Act of 1976 shares the same underlying objectives as its predecessors in that it also grants exclusive rights to "original works of authorship." 61 In the case of an essay or school paper,

intentional exercise of dominion over it, and (3) in defiance of the true owner's rights"); Agere Sys. Guardian Corp., v. Proxim, Inc., 190 F. Supp. 2d 726, 739 (D. Del. 2004) ("The tort of misappropriation lies if one attempts to usurp for its own use the results of the time and effort spent by another. While this is true, this court cannot find a case in which a party has succeeded on a misappropriation claim on similar facts." (internal footnote omitted)).

5717 U.S.C.A. $\S 301$ (a) (West 2009).

58 See Facebook, Inc. v. ConnectU LLC, 489 F. Supp. 2d 1087, 1093 (N.D. Cal. 2007) (holding that the cause of action for misappropriation was not preempted by copyright law when Facebook alleged that ConnectU misappropriated names and email addresses of its members). The e-mail addresses, themselves, could not be copyrighted, so Facebook prevailed in asserting its misappropriation claim. Id. at 1092-93. This becomes relevant if Turnitin asserts that student papers cannot be copyrighted because they are works of non-fiction with no original expression. To date, this has not occurred, yet the similarity between $i \mathrm{~Pa}$ radigms and Facebook cannot be ignored as both contain un-copyrightable elements contained in larger works of authorship that are protected and, therefore, preempted by 17 U.S.C.A. $\S 301$.

59 U.S. ConsT. art. I, § 8, cl. 8.

${ }^{60}$ Feltner v. Columbia Pictures Television, Inc., 523 U.S. 340, 351 (1998) ("In 1790, Congress passed the first federal copyright statute, the Copyright Act of 1790 ...").

${ }_{61} 17$ U.S.C.A. $\S 102$ (a) (West 2009) (explaining that authorship extends to literary works and how "[c]opyright protection subsists . . . in original works of authorship fixed in any tangible medium of expression, now known or later developed, from which they can be perceived, reproduced, or otherwise communicated, either directly or with the aid of a machine 
the rights vest in the student immediately upon fixation of the work, ${ }^{62}$ even without any form of registration. However, registration still plays an important role in determining the total rights of an author, ${ }^{63}$ and will be discussed below.

As fair use is the final key to success in both Campbell $v$. Acuff-Rose Music, Inc. and iParadigms, it will be addressed after the reproduction and distribution issues have been thoroughly discussed. ${ }^{64}$ The exclusive rights granted to an author to control duplication and distribution ${ }^{65}$ sound straightforward, but in the digital age nothing is as simple as it sounds. For example, in the past it was trivial to ascertain whether a work had been duplicated because both the original and copy existed in the tangible realm. When an author composed a manuscript, regardless of whether it went to press, a copy could be crosschecked to the original by comparing the text of each document. Today, thousands of documents exist only on computers, and because of the complex nature of electronic storage, it is often unclear whether a document has been copied. ${ }^{66}$ It can even be

or device"); see Lexmark Int'l v. Static Control Components, Inc., 387 F.3d 522, 528 (6th Cir. 2004) (explaining how the original copyright statute is embodied in the current law); see also 17 U.S.C.A. $\$ 106$ (West 2009) (detailing the exclusive rights a copyright owner has).

6217 U.S.C.A. $\$ 102$ (a). A student essay would, therefore, not only be protected upon completion and submission for grading, but it would be protected from the earliest draft.

6317 U.S.C.A $\S 412$ (West 2009) (stating that copyrighted works must be registered for an author to attempt to collect statutory damages or attorney's fees); see also 17 U.S.C.A $\S$ 410 (c) (West 2009) (making registration "prima facie evidence of the validity of the copyright," but only if the registration is completed within five years of the first publication of the work). This latter point impacts the rights of a student author whose work might be published by Turnitin without their knowledge, thereby affecting his or her ability to register for a copyright and gain the additional protections and advantages doing so provides.

${ }^{64}$ See Campbell v. Acuff-Rose Music, Inc., 510 U.S. 569, 572 (1994) (holding "that a parody's commercial character is only one element to be weighed in a fair use enquiry"); $\mathrm{Pa}$ radigms, 544 F. Supp. $2 d$ at 482 (stating that "[f]air use is a statutory exception to copyright infringement").

6517 U.S.C.A. $\S 106$ (granting the owner of a copyright the exclusive rights "(1) to reproduce the copyrighted work in copies or phonorecords; (2) to prepare derivative works based upon the copyrighted work; [and] (3) to distribute copies or phonorecords of the copyrighted work to the public by sale or other transfer of ownership, or by rental, lease, or lending").

${ }^{66}$ Consider that a document submitted to Turnitin may be copied the instant it reaches the Turnitin server. All well run commercial servers employ a technique known as redundant array of inexpensive/independent disks ("RAID"), which duplicates data across multiple hard drives on the server to prevent data loss in the case one drive fails. This is in addition to copies of the paper that may be made for both local and offsite backups. Some exceptions have been made for archival and backup use, but redundancy and backup do not mean the same thing with respect to computers. Even more copies will be made if the company is large enough to have servers strategically placed worldwide to increase performance. See 
questioned whether merely viewing a web page is considered duplication. ${ }^{67}$ For the sake of argument, it is best to focus on the most obvious copying performed by Turnitin, which takes place when it facilitates the transfer of a student paper from one instructor to another, by copying and pasting the text into an e-mail. ${ }^{68}$ This same action also accounts for the possibly unauthorized distribution of a student's work. ${ }^{69}$ Technically, the instructor of the original student's paper sends the copy to the requesting instructor, but Turnitin is a necessary party $^{70}$ that not only facilitates the transfer, but also encourages it. ${ }^{71}$

Joe Kashi, Hi-Tech in the Law Office: Practical Technology Advice for the Newly Solo or Small Firm Lawyer, 31 ALASKA B. RAG 18, 19 (2007) (explaining how RAID operates).

${ }^{67}$ See Stenograph L.L.C. v. Bossard Assocs., Inc., 144 F.3d 96, 101 (D.C. Cir. 1998) (stating that the "loading of software from some permanent storage medium, such as a floppy disk or a computer's hard drive, to the computer's random access memory ('RAM') when the software is 'booted up' causes a copy to be made" (citation omitted)). When a user requests data from a website, the remote web servers send the desired data. Depending on both the individual user's computer configuration and what other actions the computer is processing at that time, the information may be either stored in RAM or on the hard drive. In either case, a copying takes place and at least according to some courts it violates the owner's copyright. See, e.g., id. at 100 (positing that "[a]lternatively, following a line of analysis adopted by a number of courts, it can be concluded that appellants copied the software when it was booted up for use for its principal purposes, and thereby loaded into RAM"). Stenograph L.L.C. was a case where software was copied and then run, unlike Turnitin, where data is copied only to be retrieved at a later date; see also 143 CONG. REC. S12689 (daily ed. Nov. 13, 1997) (statement of Sen. Hatch) (stating the intention of the prohibition against copying by explaining that "[m]odern operating systems swap data between RAM and hard disk to use the computer memory more efficiently. Given its purpose, it is not the intent of this bill to have the incidental copies made by the user of digital work be counted more than once").

68 See TURNITIN INSTRUCtor USER Manual, supra note 26, at 46 (explaining how instructors can e-mail each other through Turnitin when Turnitin discovers a student's submission matches that of another student's submission within Turnitin's system).

${ }^{69}$ See id.; see also id. at 56 (explaining how an instructor can use Turnitin to enable peer review of students' submissions); Cf. 17 U.S.C.A. § 106(3) (granting the owner of a copyright the ability "to distribute copies ... of the copyrighted work to the public").

70 TuRnitin, supra note 26, at 46; see also Horovitz, supra note 5, at 268-69 (discussing secondary liability as it applies to Turnitin).

71 TURNITIN, supra note 26 , at 46 (explaining that Turnitin rightfully claims that only teachers can make the determination whether a work is plagiarized, and it is clear that they must allow the reviewing instructor to see the original work to make the final determination). To place this in perspective, consider the value of Turnitin's system if it did not allow for this transfer to take place. The instructor who questions his or her student's work would have no means of proving plagiarism took place either to himself or to the school's ethics committee. 


\section{B. Fair Use}

Quite obviously, the founding fathers took-and Congress takes-copyright protection very seriously, but without any qualifications the protections might be self-defeating. ${ }^{72}$ If new authors are so afraid that they may be infringing on another's rights, they may choose not to express themselves creatively and this would upset the founders' goal of promoting the arts. For this reason, the Copyright Act included a section allowing certain uses of copyrighted material to avoid infringement under special circumstances, such as if the copied work is used for "criticism, comment, news reporting, teaching-including multiple copies for classroom use-, scholarship, or research." 73 Turnitin was successful in asserting this defense in one case, ${ }^{74}$ but may face a different outcome if it is sued again in the future.

Courts first look to the statute to establish the factors they should consider and then to case law to determine how each factor should be interpreted and weighed against the others. ${ }^{75}$ One of the most cited cases on the subject, Campbell, provides considerable insight into the modern interpretation of copyright protection and fair

72 See Statutory Comm. of Unsecured Creditors v. Motorola, Inc., 218 F.R.D. 325, 326 (D.C. 2003) (stating that the "Founding Fathers ... appreciated that the protection of copyrights was crucial 'to promote the Progress of Science and useful Arts" " (quoting U.S. Const. art. I, § 8, cl. 8)); Superhype Publ'g, Inc. v. Demetrios Vasiliou, 838 F. Supp. 1220, 1224 (S.D. Ohio 1993) (stating that "[t]he wisdom of the Founding Fathers is manifest in the flowering of art and invention in this country. Congress has embodied the protections granted to authors under the Constitution in the Copyright Act, Title 17 of the United States Code").

7317 U.S.C.A. $\S 107$ (West 2009). Prior to the 1976 Act, common law doctrine applied to the fair use analysis.

74 iParadigms, 544 F. Supp. 2d at 486-87 (holding on March 11, 2008 that iParadigms' motion for summary judgment concerning its complaint should be granted); see also iParadigms, 562 F.3d at 647 ("affirm[ing] the order of the district court granting summary judgment to iParadigms ... [and] revers[ing] the grant of summary judgment to plaintiffs and remand[ing] for further consideration").

7517 U.S.C.A. \& 107 . Listing the factors:

(1) the purpose and character of the use, including whether such use is of a commercial nature or is for nonprofit educational purposes; (2) the nature of the copyrighted work; (3) the amount and substantiality of the portion used in relation to the copyrighted work as a whole; and (4) the effect of the use upon the potential market for or value of the copyrighted work.

Id. 
use exceptions. ${ }^{76}$ The defendants in Campbell were the members of a rap group known as 2 Live Crew, and composed and sold a song called "Pretty Woman," which was a parody of the similarly titled song, "Oh, Pretty Woman." lyrics were taken from the original song and incorporated into the parodying work. ${ }^{78}$ Acuff-Rose did not bring suit until after hundreds of thousands of copies were sold, ${ }^{79}$ and therefore the two exclusive rights-reproduction and distribution-were also not in dispute. Campbell's ultimate success was entirely attributed to the affirmative defense of fair use. ${ }^{80}$ The case against Turnitin differs in that both the reproduction and distribution rights are disputable, but analogous in that their success, so far, has been based entirely on a fair use defense. $^{81}$

iParadigms was in the unenviable position of having to prove fair use because sufficient evidence was brought in an attempt to hold it liable for copyright infringement. ${ }^{82}$ Although it existed only as common law until 1976, when it was added to the Copyright Act, ${ }^{83}$ fair use may have, arguably, originated in the Constitution. Because the drafters unmistakably expressed their desire to "promote the Progress of Science and useful Arts," 84 it follows logically that they also supported notions such as fair use, because they, in turn, promote the same goals. ${ }^{85}$ If the Court strictly adhered to the letter of the Copyright Act, entire genres of works, such as parodies, could not

${ }^{76}$ Campbell, 510 U.S. at 577 (stating that under "[t]he fair use doctrine" courts are not strictly bound by the copyright act because " it would stifle the very creativity which [the] law [was] designed to foster' ") (quoting Stewart v. Abend, 495 U.S. 207, 236 (1990)).

77 Id. at 572 (additionally stating that "Oh, Pretty Woman" was written by Roy Orbison and William Dees in 1964.)

78 Id. at 588 .

79 Id. at 573 (stating that over one year had passed and 250,000 copies of the new song had been sold).

80 Id. at 574 (stating that the court set out to "determine whether 2 Live Crew's commercial parody could be a fair use"); Campbell, 510 U.S. at 590 (holding that "fair use is an affirmative defense").

81 iParadigms, 544 F. Supp. $2 \mathrm{~d}$ at 484 (stating that Turnitin's use constituted fair use); see also id. at 486-87 (granting summary judgment to iParadigms).

82 iParadigms, 562 F.3d at 634 (affirming the district court's grant of summary judgment for iParadigms under the fair use doctrine).

83 Copyright Act of 1976, Pub. L. No. 94-553, § 22, 90 Stat. 2541, 2546 (1976) (amended title 17 of the United States Code).

${ }^{84}$ U.S. ConsT. art. $1, \S 8, \mathrm{cl} .8$.

85 See Dana Blankenhorn, Would Jefferson File Share?, 10 VA. J.L. \& TECH. 9, 2 (2005) (stating that the Founding Fathers intended that copyrights would be limited). 
have legally existed. As is often the case, there is no bright line rule for fair use cases, ${ }^{86}$ and at least one attorney believes extreme caution should always be exercised. ${ }^{87}$ Each case is therefore analyzed on a case-by-case basis.

The word "fair" is inherently vague, and anticipating confusion on this subject, $\S 107$ of the Copyright Act set forth four factors for the courts to use as a guide. ${ }^{88}$ The four factors are:

(1) the purpose and character of the use, including whether such use is of a commercial nature or is for nonprofit educational purposes; (2) the nature of the copyrighted work; (3) the amount and substantiality of the portion used in relation to the copyrighted work as a whole; and (4) the effect of the use upon the potential market for or value of the copyrighted work. ${ }^{89}$

It must be emphasized that these factors "shall [be] include[d],"90 but the court is not limited by them. Likewise, $\S 107$ provides examples of when fair use might be applied, ${ }^{91}$ but the list is not exhaustive, allowing for new mediums to be included. The factors are intended to be considered together, ${ }^{92}$ but for clarity it is worth analyzing each factor individually, and then combining the results.

\section{Application of First Fair Use Factor}

The first factor in the fair use assessment, "the purpose and character of the use," which lists examples of purposes such as criticism, comment, news,

\footnotetext{
${ }^{86}$ See Harper \& Row, Publishers, Inc. v. Nation Enters., 471 U.S. 539, 560 (1985) (stating that "[t]he factors enumerated in ... [17 U.S.C.A. $\$ 107]$ are not meant to be exclusive").

87 Ivan Hoffman, Fair Use: Music Sampling, 2004, http://www.ivanhoffman. $\mathrm{com} /$ fairusemusic.html (last visited May 25, 2009) (concluding that individuals should "never rely on fair use since to do so is legally very uncertain .... Always seek a license") (emphasis in original).

88 See 17 U.S.C.A. § 107.

89 Id.

90 Id.

91 Id. (stating that fair use is "for purposes such as criticism, comment, news reporting, teaching (including multiple copies for classroom use), scholarship, or research").

92 Campbell, 510 U.S. at 578.

9317 U.S.C.A § 107(1).
} 
teaching, scholarship, and research. The latter half of the factor, whether the new work is for commercial or nonprofit education purposes, is by no means dispositive, ${ }^{94}$ but it is, nevertheless, important. Taken together, the thrust of the inquiry is whether the new work is transformative or merely a copy of the original. It is not necessary for the new work to be transformative; however, "the more transformative the new work, the less will be the significance of other factors, [such as] commercialism, that may weigh against a finding of fair use." $" 95$ Turnitin, with revenues measured around ten million annually, ${ }^{96}$ has little choice but to address this factor directly.

Turnitin can potentially claim that its use of the student papers is for teaching, scholarship, or research, but this claim has a fatal flaw. The court in iParadigms calls Turnitin's use "highly transformative, ${ }^{, 97}$ because it is utilizing the works for the opposite reason that the students did. Whereas the students created the works "for the purpose of education and creative expression," to "prevent plagiarism and protect the students' written works from plagiarism." 99 If the students' use was related to education, and Turnitin's use transformed the works from an educational use to something entirely different-since it was considered highly transformative-could the use possibly still remain under the "purpose and character" meant to be protected, which is primarily "teaching . . . scholarship, or research"? ${ }^{100}$ The answer to this is not as important as

\footnotetext{
94 Harper \& Row, 471 U.S. at 562 ("The fact that a publication was commercial as opposed to nonprofit is a separate factor that tends to weigh against a finding of fair use. '[E]very commercial use of copyrighted material is presumptively an unfair exploitation of the monopoly privilege that belongs to the owner of the copyright." " (quoting Sony Corp. of Am. v. Universal City Studios, Inc., 464 U.S. 417, 451 (1984)). Campbell overruled this line of thinking when it found that the Court of Appeals made the same mistake as Harper \& Row and Sony, "[i]n giving virtually dispositive weight to the commercial nature of the parody." Campbell, 510 U.S. at 584.

95 See Campbell, 510 U.S. at 579.

96 See Dotinga, supra note 14.

97 iParadigms, 544 F. Supp. 2d at 482.

98 Id.

99 Id. It is unclear how Turnitin protects the students' works from plagiarism. The only way for a student's work to be plagiarized is if he or she, himself or herself, distribute his or her work to their peers. Therefore, the only protection he or she need is from himself or herself. Perhaps the court is referring to the rare situation in which a student's paper has been published, and therefore available to the public, and is then plagiarized. It is conceded that this would make the court's statement theoretically true, but it is still based on the student's choice to release his or her work.

100 See 17 U.S.C.A. § 107.
} 
whether plagiarism prevention is actually transformative in any way.

When a student writes an essay, his or her motivation to do so is almost entirely to satisfy the requirements of a class and to receive a grade. It is extraordinarily unlikely that any student writing an essay considers, for even a second, that his or her paper can be used to prevent plagiarism. Therefore, Turnitin claims that its use is transformative because it is using the paper in a way it was never meant to be used. ${ }^{101}$ Yet, if one breaks down the mechanics of what takes place in the plagiarism prevention, the transformative nature deteriorates quickly. A work is transformative if its use "differs from the original use in such a way that the expression, meaning, or message is essentially new." 102 Using an essay to prevent plagiarism does not modify the expression, meaning, or message in the least bit. The paper remains identical after Turnitin's "transformative" use.

Contrast this with a more traditional example of a transformative use such as the parody performed by 2 Live Crew in Campbell. In Campbell, the original was transformed through the use of new lyrics and rhythms. ${ }^{103}$ However, Perfect 10, Inc. v. Google, Inc. ${ }^{104}$ is a more apt example because it applies to digital works rather than a musical work. ${ }^{105}$ Google copied and transformed the full size images of Perfect 10, which were created originally to entertain, into smaller thumbnails that were displayed in a manner making them an "electronic reference tool." 106 Perfect 10 is often cited, alongside Sony Corp. of America v. Universal City Studios, Inc., ${ }^{107}$ as evidence that a work can still be considered transformative even if it retains a complete copy of the original. ${ }^{108}$ Unlike 2 Live Crew and Google, Turnitin does not modify the original in any way, yet, in iParadigms, the

\footnotetext{
101 iParadigms, 544 F. Supp. 2d at 482.

102 Black's Law Dictionary (8th ed. 2004) ("Transformative Use"). The entry states the origin of the word: "The term was coined by Judge Pierre N. Leval in a 1990 law-review article entitled Toward a Fair Use Standard, 103 HARV. L. REV. 1105, 1111 (1990). The concept was first applied by the U.S. Supreme Court in Campbell ...." Id.

${ }_{103}$ Campbell, 510 U.S. at 582.

104487 F.3d 701 (9th Cir. 2007).

105 Id. at 710.

106 Id. at 721.

107464 U.S. at 417 . Note that because Sony was decided before the term "transformative" was first used, it is not directly distinguished here. If one were to apply the transformative test to the copying performed in Sony today, it may not be found to be fair use as it was in 1984.

108 Campbell, 510 U.S. at 587.
} 
court found the first factor of fair use to favor Turnitin. ${ }^{109}$

One final element in the analysis of the first factor of fair use is the social benefit obtained by allowing the infringement to take place. This element is not statutorily based, but case dicta favor its inclusion in this discussion. ${ }^{110}$ Immediately before finding the first factor to favor Turnitin, the iParadigms Court mentioned that Turnitin "provides a substantial public benefit" by combating plagiarism in educational institutions. ${ }^{11}$ There is no dispute that plagiarism is a problem and that anti-plagiarism services can help fight it; but the issue is whether there is a direct and necessary connection between the social benefit and the fair use. Campbell uses similar language in its first factor analysis, finding that parodies "can provide social benefit, by shedding light on an earlier work, and, in the process, creating a new one."112 Here, though, Campbell elaborates and identifies what the social benefit is and how a parody accomplishes the benefit.

Turnitin, on the other hand, does not shed light on an earlier work or create a new one because the student papers remain unchanged. Perfect 10 acknowledges Campbell, ${ }^{113}$ and argued that a "search engine may be more transformative than a parody because a search engine provides an entirely new use for the original work, while a parody typically has the same entertainment purpose as the original work." 114 Again, Turnitin makes no change to the original work; it merely searches it and displays the results to its subscribers. Turnitin and Google both profit by displaying refined collections of other peoples' works, but only Google provides the service for free. It is because Google provides its service for free, even though it profits by displaying relevant advertisements, that it provides a public benefit. This is distinguished from Turnitin, whose benefit is not truly public because its service is neither free nor publicly available. ${ }^{115}$ In summary, Campbell and Google each use the work of another in a

\footnotetext{
109 iParadigms, 544 F. Supp. 2d at 482.

110 Perfect 10, 487 F.3d at 722.

111 iParadigms, 544 F. Supp. 2d at 482.

112 Campbell, 510 U.S. at 579.

113 Perfect 10, 487 F.3d at 721 ("[A] search engine provides social benefit by incorporating an original work into a new work, namely, an electronic reference tool.”).

114 Id.

115 See Turnitin, Select a License to Quote, http://turnitin.com/static/price.html (last visited May 25, 2009, where Turnitin offers quotes to single campuses, multiple campuses, and instructors, but not the general public.)
} 
manner that changes the original and provide it to the public for the public's benefit. ${ }^{16}$ Turnitin makes no changes to the original and provides their results only to a select few. Nevertheless, iParadigms found the first factor to favor Turnitin. ${ }^{117}$

\section{Application of Second Fair Use Factor}

The second factor, "the nature of the copyrighted work," 118 is often given less attention than the first. Campbell explained that, "[t]his factor calls for recognition that some works are closer to the core of intended copyright protection than others, with the consequence that fair use is more difficult to establish when the former works are copied."119 An original work of authorship and expression, such as a student essay, falls into the core category. This factor should favor the students, but iParadigms found that it either favors neither party or favors Turnitin. ${ }^{120}$ Therefore, iParadigms differs from both Campbell, which found that the factor was of no use, ${ }^{121}$ and Perfect 10, which favored the original creator of the work. ${ }^{122}$ This disparity begs to be addressed. Unlike Campbell and Perfect 10 , the iParadigms decision was largely based on whether " "the incentive for creativity ha[d] been diminished," "123 and the iParadigms Court found that the "use in no way diminishes the incentive for creativity on the part of students."

$i$ Paradigms is correct in diverging from the tendency to favor the original author based on the argument that the incentive for creativity has not been affected. Consider an attorney writing a brief to a

\footnotetext{
116 Perfect 10,487 F.3d at 722 . Google not only benefits the public by providing an image search feature for free, it helps the sites that it copies from as well. It is undisputed that Google's search engine drives enormous amounts of traffic to websites as does also Google's image search. Whether the remote site is funded by subscriptions as in the case of Perfect 10 , or by ads like millions of other sites, the more traffic sent to the sites the more they stand to profit from paid visitors or by ad networks.

117 iParadigms, 544 F. Supp. 2d at 482.

11817 U.S.C.A. \$ 107.

119 Campbell, 510 U.S. at 586.

120 iParadigms, 544 F. Supp. 2d at 483

121 Campbell, 510 U.S. at 586.

122 Perfect 10, 487 F.3d at 723-24.

123 iParadigms, 544 F. Supp. 2d at 482-83 (quoting Bond v. Blum, 317 F.3d 385, 396 (4th Cir. 2003)).

124 Id. at 483.
} 
court. The attorney has an incentive to be creative; to increase his chance of success, and it is in no way diminished if the court publishes his brief or makes it publicly available. Similarly, the students submitting their work to Turnitin have the same incentive to be creative: to receive a higher grade, regardless of whether Turnitin maintains a copy of their work. iParadigms reported this factor as either a tie or favoring Turnitin because it considered the incentive to create, which Campbell and Perfect 10 did not address. ${ }^{125}$

\section{Application of Third Fair Use Factor}

The third factor, "the amount and substantiality of the portion used" 126 favors Turnitin as much as the second factor. iParadigms again found that, "this factor either favors neither party or favors a finding of fair use."127 The court in iParadigms relied on the United States Supreme Court holding in Sony Corp. of America v. Universal City Studios, Inc. ${ }^{128}$ and the Ninth Circuit Court holding in Perfect $10,{ }^{129}$ which both make it clear that using even one hundred percent of the original work does not necessarily preclude a finding of fair use. ${ }^{130}$ As in Perfect 10, Turnitin's use requires it to copy entire student papers for its system to be effective, just as Google had to copy entire images for its search engine to be functional. ${ }^{131}$ However, it is unclear why ${ }^{132}$ iParadigms found this factor to potentially favor a finding of fair use, ${ }^{133}$ while Perfect 10 found this factor to favor neither party. ${ }^{134}$

\footnotetext{
${ }^{125}$ Id. at $482-83$.

12617 U.S.C.A. $\$ 107(3)$.

127 iParadigms, 544 F. Supp. $2 \mathrm{~d}$ at 483.

128464 U.S. at $449-50$.

129 Perfect 10,487 F.3d at 724.

130 See Sony, 464 U.S. at 449-50; Perfect 10, 487 F.3d at 724.

131 iParadigms, 544 F. Supp. $2 \mathrm{~d}$ at 483.

132 The cynic might point out that the court in Perfect 10 was being impartial, whereas the court in iParadigms had a bias towards Turnitin and found fair use arguments that did not exist. The relevant facts in iParadigms are too similar to those in Perfect 10, which it repeatedly cites, for iParadigms to innocently hold something even slightly different. See generally iParadigms, 544 F. Supp. 2d 473; Perfect 10, 487 F.3d 701.

133 iParadigms, 544 F. Supp. 2d at 483.

134 Perfect 10, 487 F.3d at 724.
} 


\section{Application of Fourth Fair Use Factor}

The court in iParadigms found the fourth factor, "the effect of the use upon the potential market for or value of the copyrighted work" ${ }^{\prime 135}$ to be the most important. ${ }^{136}$ Most copyright cases involve works with a calculable amount of value, but the value of a student essay is difficult to determine. Based on the assumption of some market for student papers, iParadigms cited Campbell in questioning that Turnitin's use "would result in a substantially adverse impact on the potential market for the original." ${ }^{137}$ iParadigms correctly questioned whether there is a market and whether there was any harm to the students. Finding none, it concluded that, "[b]ecause [p]laintiffs have presented no evidence of harm and the potential harm alleged is both speculative and highly unlikely, the fourth factor strongly favors a finding of fair use." 138

In this particular case, the students may not have presented evidence of harm, but it is not as speculative as the court makes it out to be. After all, Turnitin makes millions of dollars ${ }^{139}$ because of its vast archive of student papers-demonstrating that the papers have value. ${ }^{140}$ Of course, having value is not enough; the students need to either prove harm or the potential for harm. ${ }^{141}$ Perfect 10 established that every student can prove potential harm rather simply. The court explained that

[t]he right of first publication is 'the author's right to control the first public appearance of his expression.' Because this right encompasses 'the choices of when, where, and in what form first to publish a work,' an author exercises and exhausts this one-time right by

13517 U.S.C.A. \& 107(4).

136 iParadigms, 544 F. Supp. 2d at 483 (basing their conclusion on Harper \& Row, 471 U.S. at 566 , which described the fourth factor as, "undoubtedly the single most important element of fair use").

137 Id. at 483 (citing Campbell, 510 U.S. at 590).

138 Id. at 484.

139 Dotinga, supra note 14

140 It can be argued that Turnitin's value is in its proprietary algorithm, but the algorithm is useless without the student papers. Perhaps this explains why Turnitin advertises its database of papers, rather than its algorithm. See Turnitin Quick Facts, http://turnitin.com/re sources/documentation/turnitin/sales/Turnitin_Fact_Sh-eet.pdf (last visited Sept. 2, 2009).

141 iParadigms, 544 F. Supp. 2d at 483. 
publishing the work in any medium. ${ }^{142}$

The students' right to first publication is potentially taken from them every time Turnitin provides their papers to another instructor. Furthermore, because students do not know when another instructor requests their papers, they are not aware of when this right is taken away. Considering that a high percentage of Turnitin submissions have, at least, partial matches, ${ }^{143}$ a student's right of first publication is potentially taken on a regular basis. If this argument fails, the students could still bolster their argument because of their young age. Copyright protection endures for seventy years beyond the death of the creator, ${ }^{144}$ which calculates to be well over one hundred years into the future. This is a long time and courts should address this before quickly deciding there will be no potential market a century from now. Given this evidence of potential harm, and the total inability, without the assistance of subpoenas, to find actual harm, the students have a solid case in arguing that Turnitin should not be favored in the fourth fair use factor analysis. ${ }^{145}$

Students should theoretically be able to demonstrate that a competing anti-plagiarism service would offer them some compensation $^{146}$ for access to their work. Perhaps the school districts that pay

142 Perfect 10, 487 F.3d at 723 (quoting Harper \& Row, 471 U.S. at 564) (citation omitted) (in the context of Perfect 10, the court explained that because Perfect 10 had already posted its copyrighted images online it already took advantage of their right of first publication. Now that Google is also posting them, the damage is militated by the fact that Google is not the first to release the images).

143 See Turnitin Datasheet, http://www.turnitin.com/static/pdf/datasheet_search. pdf (last visited Sept. 2, 2009). Promotional material distributed by Turnitin based on internal review and unnamed independent studies reveals that, "a troubling $30 \%$ of student papers submitted contain a significant amount of unoriginal material" and up to $70 \%$ may contain minimal plagiarism. See Fig. 1, Turnitin Datasheet, http://www.turnitin.com/static/pdf/datasheet search.pdf (last visited Sept. 2, 2009).

14417 U.S.C.A. § 302(a) (West 2009).

145 One might ask whether an injunction would be appropriate in this instance. See User Agreement, supra note 27, at 9 ("You agree that under no circumstances shall you be entitled to injunctive relief with regard to the use or archiving of any paper submitted to the site.") (original all caps). Aside from the issue of this being imbalanced, it is evidence that stronger action needs to be taken against Turnitin.

${ }_{146}$ See Campbell, 510 U.S. at 572 . Even if compensation is not a realistic option, compare the facts in iParadigms to Campbell, where 2 Live Crew asked permission and offered to pay a fee to license the song they parodied. In contrast, Turnitin has certainly never offered to pay a student for his or her work, nor has it asked to license the papers on any other fair terms. Turnitin took license by forcing a unilateral contract on students who have little 
Turnitin for its service should be the most upset. Turnitin wants access to more student papers to increase the value of its system and school districts want to lower their expenses, but Turnitin gets the better end of the bargain every time. Compensating individual students is impracticable, but giving discounts to the schools would further promote the social benefit while reducing Turnitin's image as a profit hungry overseer that students cannot escape. Despite this, $i \mathrm{~Pa}$ radigms found that the fourth factor not only favored a finding of fair use, but "strongly" found in this manner. ${ }^{147}$

\section{Fair Use Conclusion}

Ordinarily, the four fair use factors would be taken into account together and balanced against each other in light of the larger picture. However, in this case, it makes no difference. iParadigms found that each of the four factors either favored neither party or favored Turnitin, ${ }^{148}$ so regardless of the weight assigned to each factor Turnitin prevails. After reading the above analysis, this conclusion seems questionable, as Turnitin should not have been favored as heavily as it was.

In this Comment's analysis of the first fair use factor, it is clear that Turnitin's use of student papers is not truly transformative, is primarily designed to pursue profit, and provides virtually no social benefit. iParadigms ignored these facts and, instead, focused on how Turnitin's use in no way paralleled the use of the students. ${ }^{149}$ Ignoring the fact that the works remained unchanged, iParadigms found that preventing plagiarism and protecting students constituted fair use. ${ }^{150}$

To arrive at its conclusion with respect to the second factor, iParadigms considered an element that neither Campbell nor Perfect 10 considered, namely the incentive to create. ${ }^{151}$ If the court's analysis were limited to whether the work was close to the core of what the statute intended to protect, the outcome would, most likely, have

\footnotetext{
or no bargaining power.

147 iParadigms, 544 F. Supp. $2 d$ at 484.

148 Id. at 481-83.

149 Id. at 482 .

$150 \mathrm{Id}$.

151 Id. at $482-83$.
} 
been different. Literary works, such as student essays, are at the heart of what should be protected. In spite of this, iParadigms dedicated a mere 132 words to the second factor's analysis. ${ }^{152}$

iParadigms' only reasonable conclusion is found in its analysis of the third factor. Relying heavily on Sony and Perfect $10,{ }^{153}$ iParadigms found that copying an entire work, when necessary to do so, does not preclude a finding of fair use. ${ }^{154}$ It is conceded that to effectively locate a plagiarized portion of a paper, one must have access to as much data as possible and it must be in its original context. ${ }^{155}$ This only comprises half of the answer though. Using the entire document does not preclude a finding of fair use, but it certainly does not favor one either. iParadigms acknowledged that the entire paper must be used for Turnitin's system to operate, but the statute does not ask the court to consider whether using the entire work is necessary, rather it questions "the amount and substantiality of the portion used in relation to the copyrighted work as a whole." 156 Taking into account the first two factors, which should not have favored Turnitin, this factor should be an additional strike against Turnitin, rather than an additional factor on its side.

Continuing the pattern of the first three factors, iParadigms found the fourth factor to strongly favor Turnitin. ${ }^{157}$ This factor is as complex as the first factor, yet major elements exist that iParadigms neglected to address, even though it considered this to be the most important factor. ${ }^{158}$ iParadigms properly focused on the effect the use would have on the potential market for the work, ${ }^{159}$ but arrived at a peculiar conclusion. Using the depositions of the students involved exclusively, ${ }^{160}$ rather than considering the impact the use would have on all students that use Turnitin, the court determined that there was no realistic market for the papers. ${ }^{161}$ Of course, further analysis would show that papers have more of a potential market than selling

\footnotetext{
152 iParadigms, 544 F. Supp. $2 \mathrm{~d}$ at $482-83$.

153 Id. at 483.

154 Id.

$155 \mathrm{Id}$.

15617 U.S.C.A. \$ $107(3)$.

157 iParadigms, 544 F. Supp. 2d at 483-84.

158 Id. at 483.

159 Id. at 484.

$160 I d$. at 484 n. 1 .

161 Id. at 484.
} 
them to websites, who then resell them to students. ${ }^{162}$ As discussed earlier ${ }^{163}$ the statute also asks about the effect on the value of the copyrighted work, and this is diminished when the students lose their right of first publication.

Unlike the position taken in iParadigms, there are countless reasons to find against fair use. Turnitin might indirectly help the public, but the substantial rights Turnitin takes away from millions of students do not outweigh Turnitin's help. Furthermore, the social benefit is slightly countered by the negative message sent to students that their hard work and copyrights are essentially worth nothing. To illustrate this, consider the following example that also has a strong public benefit, but that would most certainly not be deemed fair use. A composer orchestrates a new siren for use on emergency vehicles. This new siren uses the perfect rhythm and sound frequencies to instantly alert pedestrians and motorists without scaring them. A police officer hears this siren and decides to record it and use it on the fleet of police vehicles he maintains. Is this an example of fair use because the use strongly benefits the public? Most people would respond in the negative, but anyone relying on iParadigms would have to respond in the affirmative based on the stances it has taken. Remember, just like Turnitin, the officer makes no changes to the siren, takes the entire work, copies the siren to multiple locations, and makes use of it in his business of protecting the public. In iParadigms' defense, this hypothetical would probably not pass the first factor because the officer's use of the siren is not transformative. What if the siren was originally composed for another purposeanalogous to how student papers are written for a grade and not for plagiarism detection? In this modified example, iParadigms would have to find that using the siren should be seen as fair use if it is to remain consistent with its earlier opinions.

One can also consider another example that takes place every day, and according to iParadigms should be fair use, but has never been labeled as such. Consider a songwriter and band that compose and then perform a song to entertain their listeners. The song may

162 The court concluded that there was no market because the students involved in this litigation would not resell their papers because they thought it was cheating. Obviously, there are less scrupulous students who would have no objection to selling their papers proving there is a potential market, despite the fact that these particular students would not take advantage of it.

163 See supra Section IV.B (discussing the fair use defense). 
also be intended to provide social commentary, historical insights, and to set a desired mood. A person who has purchased a license to listen to this song, by buying a CD for example, now decides to transform a portion of the song into a ringtone. The ringtone is no longer intended to entertain, but rather to alert the user to an incoming cell telephone call. Only a portion of the song is used, and its quality is often reduced in the process. The ringtone is also not a market substitute for the original song. So far, this should satisfy the fair use test, but a five billion dollar market indicates otherwise. ${ }^{164} \mathrm{~A}$ fair use analysis of this hypothetical scenario should mirror iParadigms, and yet it does not. Unlike students trying to prove the value of and potential market for their papers, ringtones are an artificial market conjured up by the record labels. Without record label intervention, ringtones would be fair uses of legally purchased music. ${ }^{165}$

\section{PRIVACY IMPLICATIONS}

\section{A. COPPA}

The Children's Online Privacy Protection Act of 1998 ("COPPA") has only one goal: to protect the privacy of children online by dictating what privacy policies and parental consent must be acquired before a website collects personal information from children

164 See David Pogue, A Baffling New Phenomenon: Customized Ringtones, N.Y. TIMES, Sept. 13, 2007, at C9 (asserting confusion over the five billion dollar worldwide market for ringtones). Pogue asks his readers:

Question 2: If I buy and download a pop song legitimately, shouldn't I be able to trigger playback any way I want? Why must I pay one fee to play it by tapping Play, and a second fee to play it when someone calls my phone?

It just makes no sense.

Id. This question proves two points: first, the ability to play a purchased song as a ringtone should be permitted; and second, that for some reason, beyond comprehension, it is not fair use.

165 See Ben Sisario, First Royalty Rates Set for Digital Music, N.Y. TimEs, Oct. 2, 2008, at $\mathrm{C} 8$ (reporting on the recent decision made by the Copyright Royalty Board, assigning royalties to digital downloads and ringtones). This development is unnecessary proof that money and lobbying produce favorable results. If Tumitin's use of an essay can be compared to a ringtone, there should be a royalty given to the student every time Turnitin performs a search. Alternatively, ringtones should be considered as fair use and not subject to royalty payments. 
under thirteen. ${ }^{166}$ The statute, which went into effect April 21, $2000,{ }^{167}$ provides that, "[i]t is unlawful for an operator of a website or online service directed to children ... to collect personal information from a child in a manner that violates the regulations prescribed under subsection (b)," of which the pertinent section ${ }^{168}$ requires the operator, "to obtain verifiable parental consent for the collection, use, or disclosure of personal information from children."169 Turnitin does not hide the fact that they collect personal information. ${ }^{170}$ Despite claims to the contrary, ${ }^{171}$ the Turnitin service is also aimed at children under thirteen. ${ }^{172}$ This appears to be a blatant violation of COPPA, and yet it still does not uncover the full extent of the potential damage.

Unlike the typical website that COPPA was intended to control, such as sites with birthday clubs and games, Turnitin not only collects the names of children, but their essays as well. Essays that may contain even more personal information about family history, financial history, and even abuse, are also collected. This is hardly rectified by the external appearance of compliance by having an easily locatable privacy policy.

COPPA also requires operators to take additional precautions

166 Federal Trade Commission: Protecting America's Consumers, How to Comply With The Children's Online Privacy Protection Rule, http://www.ftc.gov/bcp/edu/pubs/business/ idtheft/bus45.shtm (last visited Aug. 29, 2009).

$167 \mathrm{Id}$.

16815 U.S.C.A $\$ 6502$ (b)(1)(A)(ii) (West 2009).

169 Id.; Federal Trade Commission, supra note 166.

170 Turnitin, Privacy Pledge at 2, http://tumitin.com/static/pdf/Privacy_Pledge .pdf, ("[W]e collect contact information such as name, IP address, physical address, telephone number, and email address for a registered user in order to facilitate use of the Turnitin service and facilitate customer relations."). See also id. at 2 (defining "personal information" to mean individually identifiable information about an individual collected online, including (A) a first and last name; (B) a home or other physical address including street name and name of a city or town; (C) an e-mail address; (D) a telephone number). It is clear that Turnitin collects the exact types of information that COPPA sets out to protect. $I d$. at 2.

171 See id. at 4.

172 Turnitin markets its service to elementary schools all of which teach students under the age of thirteen. See Rachel V. Smydra, The Challenge of Plagiarism Control in Universities and Colleges, in ASSOCIATION FOR BUSINESS COMMUNICATION, PROCEEDINGS FROM THE 69TH ANNUAL CONVENTION: EXPLORING THE IMPACT OF TECHNOLOGY ON BUSINESS Communication Practice AND Pedagogy 260 (Jeanette S. Martin ed. 2004), available at http://businesscommunication.org/conventions/Proceedings/2004/PDFs/24ABC04.PDF.

The usage agreement entered into by students also contains a provision targeted towards children under thirteen, confirming that Turnitin is aware that these children use their service. Privacy Pledge, supra note 170, at 4. 
when personal information is sent to third parties. ${ }^{173}$ The ramifications of this are obvious, when taken into account with the fact that children are not informed that their personal information may be sent to third parties, nor are their parents consulted or informed. ${ }^{174}$ Once again, unless some measure of control is in place that the public is unaware of, Turnitin faces a serious COPPA violation.

\section{B. FERPA}

The Family Educational Rights and Privacy Act $^{175}$ ("FERPA") dictates that schools and their agents must have written permission from a parent or adult student before releasing information from a student's record. ${ }^{176}$ Turnitin claims to comply with FERPA guidelines restricting disclosure of student records, but if student essays are part of their school records, this is patently violated every time Turnitin sends a student paper to a third party. ${ }^{177}$ Turnitin claims to comply with this act specifically, ${ }^{178}$ yet if the quote made by its founder under oath has any merit, ${ }^{179}$ this is difficult to

173 Federal Trade Commission, supra note 166, at 32.

When operators want to disclose a child's personal information to third parties or make it publicly available (for example, through a chat room or message board), the sliding scale requires them to use a more reliable method of consent, including: getting a signed form from the parent via postal mail or facsimile; accepting and verifying a credit card number in connection with a transaction; taking calls from parents, through a tollfree telephone number staffed by trained personnel; email accompanied by digital signature.

Id.

174 Turnitin Training Center, http://turnitin.com/static/training.html (last visited Sept. 13, 2009), which explains that when a student paper is a potential match only their instructor is given notice of this and has the sole power to distribute the paper. At no time is the student informed and at no time is their parent informed.

17520 U.S.C.A. $\$ 1232 \mathrm{~g}$ (West 2009).

17620 U.S.C.A. $\$ 1232 \mathrm{~g}$ (b)(1)(A)-(J). Certain disclosures require no consent, such as those made under subpoena or in connection with required administrative duties.

177 Reihman, supra note 18 (demonstrating that a university spotted the potential FERPA violation and cautioned its instructors on how to avoid violations).

178 Turnitin IP Datasheet, http://turnitin.com/static/pdf/datasheet_ip.pdf (last visited May 25, 2009).

179 Appellant's Reponse and Reply Brief at *2, iParadigms, 562 F.3d 630 (Nos. 08-1424, 08-1480) (asserting that the Turnitin founder, Dr. John Barrie, said during depositions that Turnitin "does not and cannot keep track of who requests archived student manuscripts, or who it sends them to"). If Turnitin cannot keep track of who requests student papers, how can they possibly comply with FERPA, which requires that they get written permission be- 
accept as true.

\section{Privacy Conclusion}

Despite claims to the contrary, Turnitin violates at least two major United States privacy laws. ${ }^{180}$ While this is relevant in and of itself, it should also be noted that it bears on the fair use analysis above. As more evidence is uncovered demonstrating that Turnitin violates privacy laws, it becomes more difficult to accept its argument of social benefit. No court should favor Turnitin if its hands are unclean in this manner.

\section{Alternatives TO THE TURNITIN MOdeL}

\section{A. Modified Turnitin}

As the case against Turnitin mounts, one final blow strikes deep into Turnitin's heart. Until this point, significant leeway has been given to Turnitin because of its alleged benefit to society, which somehow outweighs its wrongdoings. However, if alternatives exist to Turnitin, then it becomes unnecessary to be so generous. Individual teachers are in the best position to combat and prevent plagiarism as both educators and mentors, ${ }^{181}$ but technical solutions unquestionably have a place.

Rather than scrap a functioning system, though, it is worth the effort to see if the Turnitin model can be salvaged. The first alternative to Turnitin, therefore, is not a true alternative, but a modification of the current system. The first of the two major copyright infringements - namely reproducing and duplicating the paper-could be instantly quashed if Turnitin elects to have archiving of student papers an opt-in feature. Rather than rely on a clause in a one sided contract, students should be given the right to selectively choose which,

fore disclosing the papers?

180 Turnitin also claims to properly abide by the Canadian privacy law known as the Personal Information Protection and Electronic Documents Act ("PIPEDA"), but this claim is outside the scope of this Comment. Turnitin IP Datasheet, supra note 178.

${ }^{181}$ UCLA Office of Instructional Development, Toward a Less Controversial Use of Turnitin http://www.oid.ucla.edu/training/trainingarticles/turnitin/turnitin-2b (last visited October 25, 2009). 
if any, of their papers they want added to the Turnitin archive. Of course, the current back door that allows teachers to submit papers would either need to end ${ }^{182}$ or, at the very least, never allow archiving.

The second hurdle that the modified Turnitin system would have to overcome relates to the distribution of student works without notice or consent. Again, an opt-in system that allows students to choose whether they want to be notified of potential matches is simple to implement. ${ }^{183}$ At the very least, the current system, which involves e-mail communications between the two instructors, should be changed so that the original student is contacted rather than their former teacher. This would allow the copyright owner, rather than an uninterested former teacher, to make the decision on a case-by-case basis of whether he or she wants to share his or her work. ${ }^{184}$

This alternative not only resolves the copyright infringement, it involves the students in the fight against plagiarism as well. Turnitin can still advertise itself as having a large archive of student works, and its business model would remain unchanged.

\section{B. Similar Services}

Turnitin is by no means the only commercial anti-plagiarism service, and even free services remain competitive in this field. One well-regarded commercial option is the Essay Verification Engine ("EVE"). ${ }^{185}$ EVE behaves in a similar fashion to Turnitin, but has a different business model. Rather than market itself to large institutions in order to sell subscriptions, EVE is a downloaded application that has a flat fee instead of a per student cost. ${ }^{186}$ More relevant,

182 Removing this ability entirely is the safest approach if there is even a chance of privacy violations. Every student today either has a personal computer or access to one in his or her local library or school and so there is no justifiable reason to allow teachers to upload any documents that are not their own. See Martina Simos, Nightly Battle on the Home Front, ADVERTISER, June 26, 2001, at 33.

${ }_{183}$ Students must submit email addresses and other contact information when they register with Turnitin. See Turnitin, Privacy Pledge at 1-2, (Nov. 12, 2004), http://turnitin.com/ static/pdf/Privacy_Pledge.pdf.

184 This might also have the unintended consequence of teaching honest students not to give away their hard work and dishonest students how easily they can be caught.

${ }_{185}$ See EVE2 Home Page, http://www.canexus.com/index.shtml (last visited May 25, 2009).

186 Id. 
though, is that EVE does not archive or distribute student papers. Students must furnish a digital copy of their essays to their instructors to perform the check, but this can be returned. ${ }^{187}$ In fairness to Turnitin, it must be noted that EVE cannot detect plagiarism of other student papers or even previously submitted papers like Turnitin; but to many, this is a small sacrifice to gain privacy and control over intellectual property.

One free alternative to Turnitin is the popular search engine Google. ${ }^{188}$ The benefit of using Google is twofold: it is free; and it is also what many students used to plagiarize in the first place. Google is also extremely fast and simple to use, and teachers have the option of typing in questionable phrases even if they do not have digital versions of the student essays they are grading. Google has limitations: it cannot read papers from sites protected by passwords, but this is outweighed by its versatility.

\section{Alternatives Through Policy}

Turnitin is not the exclusive technological solution to fighting plagiarism. ${ }^{189}$ Simple policy changes and carefully constructed assignments have equal power to prevent plagiarism. For example, assignments that require individual analysis rather than a compilation of facts are more difficult to plagiarize. Requiring students to submit drafts and copies of cited sources is also an effective way to reduce plagiarism. Bedford-St. Martin, a publisher of college textbooks, offers a number of strategies, such as having students create a "knowledge of inventory," incrementally collecting work, and having students submit research portfolios. ${ }^{190}$ Lehigh University suggests that

\footnotetext{
187 Plagiarism Software Evaluation for eleUM (2004), http://www.fdewb.unimaas.nl/ eleum/.

188 Aurora University, Getting Started with Turnitin, http://www.aurora. edu/studentlife/resources/its/turn-it-in.html (last visited Sept. 3, 2009).

189 Other options not discussed include: mydropbox.com, doccop.com, copycatchgold.com, and plagiarismdetection.org. Park University Homepage, Faculty Resource Quick Tips, http://www.park.edu/cetl/quicktips/plagiarism.html (last visited Sept. 13, 2009); PlagiarismDetection.org Homepage, http://www.plagiaris mdetection.org/ (last visited Sept. 13, 2009).

190 See Nick Carbone, Using Portfolios to Avoid Plagiarism in Your Classes, http://www.bedfordstmartins.com/technotes/workshops/avoidplagiarism.htm (last visited on May 25, 2009).
} 
teachers collect a draft and check it for plagiarism ${ }^{191}$ to catch it early and help students revise their final paper to correct any mistakes.

With plenty of alternatives to Turnitin, schools can and should make the first step towards supporting their students' intellectual property rights. This can be accomplished by choosing a system or policy that provides an appropriate balance between questionable infringement and accepted fair use.

\section{Conclusion}

The sad fact is that throughout this Comment only one aspect has had any consistency, and that is that students, with no financial resources, are being taken advantage of at every turn. From the moment the student agrees to the one-sided contract with Turnitin, until the conclusion of the fair use analysis, one can see how a lack of bargaining power is an enormous disadvantage. Every fair use factor can be equally interpreted to favor the students, yet Turnitin prevails anyway. There is no question that if student essays were treated more like songs, the result in iParadigms would have been flipped on its head. Adding insult to injury are the growing privacy implications set forth. With no meaningful choice, students by the million are being forced to sacrifice their privacy and copyrights to hopefully catch the few of their peers that have plagiarized. Every student that has read Orwell's 1984 can tell you what happens when the state watches your every move and places no faith in society because of the activities of a minority. These same students will be the leaders of the next generation, and it is not in America's best interest to have them perpetuate the distrust that is being thrust upon them.

Plagiarism remains a serious problem, but Turnitin no longer seems to be the answer.

191 See supra note 18. 
Touro Law Review, Vol. 26, No. 1 [2011], Art. 7 